\title{
The influence of altitude on the distribution of subterranean organs and humus components in carpets of Vaccinium myrtillus (L.)
}

\author{
Frak, Elzbieta \& Ponge, Jean-François* \\ Museum National d'Histoire Naturelle, Laboratoire d'Écologie Générale, 4 avenue du Petit-Chateau, \\ 91800 Brunoy, France; * Corresponding author; Fax +33160465009; E-mail jean- \\ francois.ponge@wanadoo.fr
}

\begin{abstract}
Humus profiles were sampled along an altitudinal gradient in the Macot-La-Plagne Forest (France, Northern Alps) in order to describe the variation occurring under carpets of bilberry [Vaccinium myrtillus (L.] present within spruce forests. The vertical distribution of subterranean organs of bilberry (rhizomes and roots) was compared with i) that of spruce roots and other accompanying vegetation, ii) other components of humus profiles, in particular humified organic matter, mainly consisting of recent and old animal faeces. It was shown that bilberry roots were mostly concentrated in mineral horizons, while spruce roots and bilberry rhizomes rather occupied litter horizons. This was interpreted in terms of a strategy for capturing nutrients in the frame of the competition between spruce and bilberry. The effects of altitude were i) a change in the vegetation accompanying bilberry in dense bilberry carpets, bryophytes at the montane level being replaced by forbes at the subalpine level, ii) a decrease in the thickness of ectorganic horizons. This was interpreted as a shift from a moder system characterized by recalcitrant litter (moss) processed by an active faunal community (stabilized in the form of animal faeces), to a mor system characterized by low animal abundance but with litter of better quality which is easily leached in the absence of prominent faunal activity.
\end{abstract}

Keywords: Animal faeces, Bilberry, Humus form, Mountain, Rhizome, Root, Spruce

Nomenclature: Rameau et al. (1993) for plant species, Brêthes et al. (1995) for soil horizons. 


\section{Introduction}

The age structure and the growth dynamics of bilberry (Vaccinium myrtillus L.) are well-known since the thorough examination of bilberry patches of varying age done by Flower-Ellis (1971) in Scotland. The rhizome of this acidophilic ericaceous shrub grows sympodially, forming clonal carpets which enlarge and densify in the course of time and accumulate raw humus (Bernier et al. 1993; Bernier \& Ponge 1994; Maubon et al. 1995). The foliage of bilberry is deciduous and is richer in nutrients than that of most other Ericaceae, its soft leaf litter decaying easily despite a high tannin content (Gallet \& Lebreton 1989; Gallet \& Lebreton 1995). Given the nutritional demand of V. myrtillus (Ingestad 1973) we may wonder how it does not suffer from the shortage of nutrients resulting from podzolisation and the immobilization of nitrogen in the form of tannin-protein complexes (Wardle et al. 1997; Northup et al. 1998). The association of roots with mycorrhizal fungi able to use recalcitrant organic matter as a nitrogen source has been thought to explain the growth of ericaceous species in raw humus with a very low biological activity (Read \& Kerley 1995; Näsholm et al. 1998). Nevertheless examination of the subterranean parts of bilberry reveals that raw humus is occupied by rhizomes while most roots grow more or less vertically through the mineral soil (Heath et al. 1938). Thus bilberry seems to exhibit a double strategy for capturing nutrients, by exploring the organic horizon with its rhizome system and the mineral soil with its root system.

In European mountains bilberry is commonly found in association with Norway spruce [Picea abies (L) Karst.], at least at the subalpine level (Gensac 1970). Recent studies revealed that Norway spruce and bilberry were in fact competing for the same micro-sites during their establishment, both germinating and growing better on mineral soils (André 1994; Ponge et al. 1998) and exhibiting biochemical-mediated antagonisms once established (Gallet 1994; Maubon et al. 1995; Jäderlund et al. 1996; Jäderlund et al. 1997). It was concluded that the development of bilberry as dense permanent carpets was favoured by thinning operations done in spruce forests, resulting in lack of spruce regeneration and thus in the long-term in a collapse of the forest ecosystem (Ponge et al. 1998). Within dense billbery heath, spruce cannot establish successfully by seed. Conversely, bilberry declines when spruce crowns enlarge (Ponge et al. 1994; Maubon et al. 1995), possibly due to a combination of shading and nutrient depletion (Christy 1986). We may wonder how the antagonism 
between bilberry and spruce is expressed when the subterranean parts of both species are present, as this is the case in dense bilberry carpets within bilberry-spruce forests, for instance by exploiting distinct horizons.

The thickness of organic matter accumulating on the forest floor in bilberry carpets has been observed to decrease with altitude (Ponge et al. 1998). This finding apparently contradicts the rule that more organic matter acccumulates in the soil when the climate becomes colder and the substrate becomes poorer as occurs at higher elevation (Lichtenegger 1996; Körner 1999). The examination of the composition of organic matter (plant debris, animal faeces) might throw light on this unexpected phenomenon.

In order to answer the three above mentioned questions, it was decided to analyse the composition of humus profiles along an altitudinal gradient, in the Macot-La Plagne forest, where $V$. myrtillus and $P$. abies co-exist, dominating the forest/heath patchwork from the montane to the subalpine level (Gensac 1970; Ponge et al. 1994; Maubon et al. 1995). Micromorphological methods according to Ponge (1984), later on modified by Bernier \& Ponge (1994), proved useful to quantify the composition of soil horizons at varying depths and compare humus profiles (Ponge 1999; Peltier et al. 2001). They were used in the present study, rather than washing techniques (McQueen 1968; Messier \& Kimmins 1991; Dighton \& Coleman 1992; Ehrenfeld et al. 1997), in order to estimate the abundance of fine roots. Together with dead and living plant parts, other components of humus profiles (animal faeces, mineral matter) will be quantified and compared from horizon to horizon and between humus profiles in order to characterize soil organic matter.

\section{Study site}

The Macot forest (Macot-la-Plagne, Savoy, France) is located on a north-exposed slope along the Tarentaise Valley, in the French northern Alps. The elevation ranges from 800m (near the Macot village) to $2100 \mathrm{~m}$ (at the base of Mount Saint-Jacques). The substrate is poor in nutrients, arising from graywackes, schists and quartzites, with soils being acidic throughout. Due to a combination of favourable factors such as colluvial deposits and higher biological activity, the bottom of the slope is 
characterized by richer soils. Thus, there is a gradient of increasing soil acidity with altitude (Loranger et al. 2001). Spruce is the dominant tree species, mixed with silver fir (Abies alba Mill.) at the montane level and with cembra pine (Pinus cembra L.) at the subalpine level, European larch (Larix decidua L.) being sparsely distributed over the whole altitudinal range. Bilberry is present at small isolated spots on rocky outcrops at the lower montane level, the size of carpets increasing with altitude, extending as pure ericaceous heath above the timberline, in admixture with other ericaceous species such as Vaccinium vitis-idaea L., Rhododendron ferrugineum L. and Arctostaphylos uva-ursi L. The higher montane and the lower subalpine levels are characterized by a mosaic assemblage of spruce forest and bilberry heath (the so-called bilberry-spruce forest) as a result of succession processes and sylvicultural practices (Bernier \& Ponge 1994; Ponge et al. 1994; Maubon et al. 1995; Ponge et al. 1998). Bilberry was often found associated with two mosses [Rhytidiadelphus triquetus (Hedw.) Warnst., Hylocomium splendens (Hedw.) B., S. \& G.) and two grass species, the wavy hair-grass [Avenella flexuosa (L.) Parl.] and the greater wood-rush [Luzula sylvatica (Huds.) Gaud.].

\section{Material and methods}

Carpets of bilberry were sampled along a transect crossing the whole altitudinal range where bilberry was found in dense carpets. At 950, 1470, 1650, 1870 and 2150m a.s.l., after a cursory examination of physiognomic mosaics, one to three plots were selected representing the variety of bilberry carpets prevailing on the site. A total of 12 plots were thus selected for sampling humus profiles. Sites at 950 (2 samples) and 1470m (one sample) were the same as in Bernier \& Ponge (1994) and Bernier (1996). Sites at 1650 (3 samples) and 1870m (3 samples) were the same as in Bernier et al. (1993). The site at 2150m (3 samples) was the same as in Ponge et al. (1994). At the centre of each plot a small humus block $5 \times 5 \times 15 \mathrm{~cm}$ (Ixwxh) was prepared with a sharp knife and the different layers were separated by hand and put immediately to small plastic jars filled with $95 \%$ ethyl alcohol.

The fixed material was examined under a dissecting microscope by pouring it, with as less disturbance as possible, in a Petri dish filled with ethyl alcohol. A transparent sheet with 600 points marked on it was put over the material and covered with alcohol, allowing for an estimation of the 
volume of the different humus components in each layer. In order to increase the number of points, and thus the precision of the measurement, the grid was randomly displaced at the end of a counting run in order to allow for a new set of 600 points to be counted. This procedure was necessary for estimating the volume of very fine roots of bilberry. When no objects were visible under a point at the 40x magnification, the point was discarded. The total number of points taken into account for a given layer varied from 336 to 1603 .

Plant organs were determined by help of a collection of main plant species growing in the vicinity of the sampled humus profiles: aerial and subterranean parts were fixed separately into ethyl alcohol and observed in the same conditions as humus components. Animal faeces and bodies were identified by morphological features (size, shape, colour, size of ingested particles) according to experience of the junior author.

Data were analysed by simple correspondence analysis (Greenacre 1984), which has been successfully applied to micromorphological data, allowing humus profiles as well as horizons to be compared and classified on the basis of their composition (Ponge 1999; Peltier et al. 2001). Humus components were used as active variables and layers of all humus profiles were used as observations. The five altitudes $(950,1470,1870$ and $2150 \mathrm{~m})$, the three arbitrary depth levels $(0-5,5-$ 10 and $10-15 \mathrm{~cm})$ and the different horizons found (OL, OF, OH, A, E, B, S, rodent mound) were each used as passive variables. All variables were standardized, their mean being fixed to 20 and their variance to 1 , for interpreting factorial coordinates as contributions to factorial axes (Ponge and Delhaye 1995).

Given the absence of replication, no testing of hypothesis can be achieved on this data set, correspondence analysis being used only to reveal patterns hidden in a complex data matrix. Nevertheless, the significance of the first axis of correspondence analysis was tested by correlation analysis (Sokal \& Rohlf 1995), as well as the effect of altitude on organic matter accumulation.

The mean depth of a humus component in a given profile was calculated using the vertical distribution of its percentage of occurrence. Thus each humus component can be characterized by an 
array of twelve average depths, one for each profile. In turn, these average depths can be averaged, in order to give a global average depth (labeled mean depth) indicating the mean vertical position of a given humus component.

\section{Results}

One hundred and fifty-nine humus components were identified in the whole set of 53 samples (Table 1). A projection of humus components (active variables) and passive variables (elevation, depth level, horizon) in the plane of the first two axes of correspondence analysis ( $13 \%$ and $9 \%$ ot total variance, respectively) revealed the influence of depth and altitude on the distribution of humus components and plant organs (Fig. 1). Axis 1 was correlated with depth (Fig. 2), thus it can be used to scale the different humus components according to their vertical distribution.

Bilberry rhizomes (5) were mostly found at the base of litter horizons (positive side of Axis 1 , but not far from the origin) while roots of varying size $(7,8,9)$ were mostly found in mineral or organomineral horizons (negative side of Axis 1, far from the origin). Dead rhizomes (6) were projected on the negative side of Axis 1 , indicating that in the course of time they became buried in the upper part of mineral horizons. Figure 3 shows that in a humus profile at $1870 \mathrm{~m}$ altitude (micro-podzol) rhizomes were located only in litter horizons, being most abundant in the $\mathrm{OH}$ horizon. They were absent from the mineral soil. On the contrary, bilberry roots were increasing in volume from the litter to the mineral soil, being most abundant in the $B$ horizon where ramification occurred, the $E$ horizon being only crossed by vertical roots. Figure 4 shows the distribution of bilberry rhizomes and roots in a humus profile perturbed by rodent activity. Examination of this particular profile revealed that roots colonized preferably mineral horizons, like in the previous case, but also that rhizomes could grow in the mineral soil when loose (backfilling horizon).

Contrary to bilberry, the fine root system of spruce $(22,24,26,27,46)$ was most abundant in litter, which was confirmed by examination of individual profiles (Figs. 3 and 4). The preference of spruce roots for litter horizons was even still marked than that of bilberry rhizomes. Grass roots (70, 
$71,80,89,90,91$ ) were most abundant in mineral horizons (negative side of Axis 1), but in a more shallow position than roots of bilberry, their corresponding points being projected nearer the origin.

Enchytraeid, arthropod and epigeic earthworm faeces (126, 127, 128, 129, 130, 131, 132, 133) were projected on the positive side of Axis 1, approximately at the same level as spruce mycorrhizae, i.e. in $\mathrm{OH}$ horizons (Fig. 1). Enchytraeid faeces (126) should be considered as an important component of $\mathrm{OH}$ horizons, into which they may constitute up to $24 \%$ of the total matrix volume. Earthworm organo-mineral faeces $(135,136)$ were projected on the negative side of Axis 1 , not too far from the origin (Table 1), thus they rather characterized A and "Mound" horizons. Old organo-mineral earthworm faeces $(139,140,141,143,144,145)$ were projected roughly at the same level as dead spruce roots $(24,25)$ and dead bilberry rhizomes (6).

The projection of active and passive variables on Axis 2 indicated a variation in the composition of litter only, the mineral part of the humus profile exhibiting weak variation along this axis. The scaling of the five altitudes along Axis 2 indicated that this axis reflected the effects of elevation on the composition of litter in bilberry carpets. The montane level (950 and 1470m altitude) was characterized by mosses $(52,53,54,57,58,59)$, liverworts $(55,56)$, Oxalis acetosella L. $(114$, 115), V. vitis-idaea (111) and A. alba (37), while the subalpine level was characterized by Asteraceae (102, 105), L. sylvatica $(62,63,64,65,66,67)$, Alchemilla alpina L. $(116,117)$, L. decidua $(38,39)$ and P. cembra $(40,41)$. V. myrtillus $(1,2,3,4)$ and $A$. flexuosa $(82,83,84,85,86,87,88)$ were projected on the negative side of Axis 2, but not far from the origin. Both species can be considered as constant members of bilberry carpets throughout the altitudunal gradient.

The projection of holorganic faecal components typical of $\mathrm{OH}$ horizons $(126,127,128,130$, $131,132,133)$ on the positive side of Axis 2 , together with litter components typical of the montane level $(37,52,53,54,55,56,57,58,59,111,114,115)$ indicated that $\mathrm{OH}$ horizons, typical of moder humus forms (Brêthes et al. 1995), were mostly expressed at low elevation. Thus more organic matter accumulated at the top of soil profiles at the montane compared to the subalpine level. Figures 5 and 6 show that the total thickness of litter horizons and the mean relative volume of animal faeces (only fresh, recognizable material, taken into account) decreased significantly with altitude. 


\section{Discussion}

Our first work hypothesis was a double strategy for the use of soil nutrients by the subterranean parts of bilberry. The present results, although based on a limited number of samples, pointed to dissimilarities between the vertical distribution of roots, which prevailed in mineral horizons, and rhizomes, which prevailed in organic horizons. We have shown that when the soil was wellaerated, like in the case of rodent mounds, rhizomes were able to penetrate the soil deeply (Fig. 4). This had been also observed in mull humus forms typical of the first (pioneer) stages of colonization by bilberry (André 1994; Bernier \& Ponge 1994; Maubon et al. 1995; Ponge et al. 1998). We hypothesize that the main reason for the lesser abundance of bilberry rhizomes in $\mathrm{E}, \mathrm{B}$ and $\mathrm{S}$ horizons and in the A horizon of moder humus is the compact nature of these horizons, due to weak faunal activity, in particular the absence of interconnected pores of enough size (Brêthes et al. 1995). This could explain why the rhizome system of bilberry, the plagiotropism of which has been observed in culture (Barker \& Collins 1963, working on the closely related species Vaccinium angustifolium Ait., grew worse when it encountered mineral horizons in a mountain slope, resulting in a preferentially downsloping growth (Maubon et al. 1995). Contrary to rhizomes, the diameter of which exceeds one $\mathrm{mm}$ near their growing apex (personal observations), the diameter of fine roots of bilberry is less than $0.1 \mathrm{~mm}$. Thus the root system of bilberry is better adapted than the rhizome system to penetrate compact mineral horizons where pores created by enchytraeids are of sufficient size (Ponge 1999; Topoliantz et al. 2000).

Our second work hypothesis was that spruce and bilberry were spatially segregated within the soil profile. The present results do not show such segregation, bilberry rhizomes and spruce roots exploiting together the same litter horizons. Nevertheless the root system of bilberry escapes from competition by spruce, by exploiting preferably mineral horizons. Thus in a podzolic soil bilberry will be able to derive nutrients from the illuviation $B$ horizon, where bases leached from litter by colloid transport accumulate (Goldberg et al. 2000), which spruce cannot do due to the scarcity of roots in this horizon (Fig. 3). This point may be of paramount importance if we consider the podzolizing effects of bilberry, probably due to the high production of $p$-coumaric and protocatechuic acids by senescing 
foliage, increasing with altitude (Gallet \& Lebreton 1995), to be a mean by which this ericaceous shrub may alleviate competition by spruce and thus may form dense carpets to the detriment of spruce, together with the biochemical inhibition of spruce germination and seedling growth (Gallet 1994; Jäderlund et al. 1996).

The last point to be elucidated was the decrease with altitude of the accumulation of organic matter at the top of soil profiles. This phenomenon, already noted by Bernier (1997), has been confirmed by the present results about litter thickness (Fig. 5) and amount of animal faeces within humus profiles (Fig. 6). Several reasons can be postulated to explain this phenomenon, i) a decrease in primary productivity, ii) a decrease in the recalcitrance of litter to leaching and decomposition, iii) a decrease in the intensity of humification processes. The present study cannot address all these points, since we did not measure plant production nor carbon fluxes in the soil system, but it should be highlighted that we observed a decrease with altitude in the bryophytic component of bilberry carpets, the herb component increasing accordingly. This could be thought to be at the origin of some improvement of litter quality, given the well-known recalcitrance of moss litter towards decomposition (Kilbertus 1968; Ponge 1988), but we must point out that signs of animal activity typical of a rapid disappearance of litter (in particular earthworm activity) did not seem to increase with altitude. In particular all components of faecal material were projected on the positive side of Axis 2 of correspondence analysis (Fig. 1), thus were associated with the montane level rather than with the subalpine level. If we consider that the abundance of animal faeces in humus profiles reflects the level of animal activity (Topoliantz et al. 2000) we must conclude that animal activity decreases with altitude, which indicates a shift from Moder/Mull (both humus forms with a high level of animal activity) to Mor (Ponge et al. 2000; Ponge submitted), despite the observed decrease in litter thickness.

We suspect the leaching of colloidal and soluble organic matter to interact with organic matter accumulation. The decrease in animal activity from the montane to the subalpine level may have farreaching consequences on humificative processes. If the amount of animal faeces decreases, then more small-sized organic molecules will be leached down the soil profile without being stabilized within big-sized humic assemblages (animal faeces, microbial biomass), according to the podzol model (Kononova 1961; Schoenau \& Bettany 1987). Thus a large part of the organic matter produced by 
vegetation could escape accumulation at the top of soil profiles while accumulating deeper in B horizons. Given that mosses act as a sponge by retaining water and nutrients coming from precipitation and throughfall (Tamm 1953; Bates 1987), we suspect that organic and mineral molecules present in moss litter cannot be leached so easily than those present in grassy and even bilberry litter (Gallet \& Lebreton 1995). Thus both phenomenons, the decrease in the amount of moss litter and the decrease in the deposition of animal faeces may concur synergistically in more leaching of organic matter at the subalpine level, thus in a reduced thickness of accumulated litter.

\section{References}

André, J. 1994. Régénération de la pessière à myrtille: allélopathie, humus et mycorhizes. Acta Bot. Gallica 141: 551-558.

Barker, W.G. \& Collins, W.B. 1963. The blueberry rhizome: in vitro culture. Can. J. Bot. 41: 13251329.

Bates, J.W. 1987. Nutrient retention by Pseudoscleropodium purum and its relation to growth. J. Bryol. 14: 565-580.

Bernier, N. 1996. Altitudinal changes in humus form dynamics in a spruce forest at the montane level. Plant Soil 178: 1-28.

Bernier, N. 1997. Fonctionnement biologique des humus et dynamique des pessières alpines. Le cas de la forêt de Macot-La Plagne (Savoie). Ecologie 28: 23-44.

Bernier, N. \& Ponge, J.F. 1994. Humus form dynamics during the sylvogenetic cycle in a mountain spruce forest. Soil Biol. Biochem. 26: 183-220.

Bernier, N., Ponge, J.F. \& André, J. 1993. Comparative study of soil organic layers in two bilberryspruce forest stands (Vaccinio-Piceetea). Relation to forest dynamics. Geoderma 59: 89-108. 
Brêthes, A., Brun, J.J., Jabiol, B., Ponge, J.F. \& Toutain, F. 1995. Classification of forest humus forms: a French proposal. Ann. Sci. For. 52: 535-546.

Christy, E.J. 1986. Effect of root competition and shading on growth of suppressed western hemlock (Tsuga heterophylla). Vegetatio 65: 21-28.

Dighton, J. \& Coleman, D.C. 1992. Phosphorus relations of roots and mycorrhizas of Rhododendron maximum L. in the southern Appalachians, North Carolina. Mycorrhiza 1: 175-184.

Ehrenfeld, J.G., Parsons, W.F.J., Han, X., Parmelee, R.W. \& Zhu, W. 1997. Live and dead roots in forest soil horizons: contrasting effects on nitrogen dynamics. Ecology 78: 348-362.

Flower-Ellis, J.G.K. 1971. Age, structure and dynamics in stands of bilberry (Vaccinium myrtillus L.). Royal College of Forestry, Stockholm, Department of Forest Ecology and Forest Soils, Research Note $N^{\circ} 9$.

Gallet, C. 1994. Allelopathic potential in bilberry-spruce forests: influence of phenolic compounds on spruce seedlings. J. Chem. Ecol. 20: 1009-1024.

Gallet, C. and Lebreton, P. 1989. Profils phytochimiques au sein d'une pessière d'altitude. Acta Biol. Mont. 9: 143-152.

Gallet, C. \& Lebreton, P. 1995. Evolution of phenolic patterns in plants and associated litters and humus of a mountain forest ecosystem. Soil Biol. Biochem. 27: 157-165.

Gensac, P. 1970. Les pessières de Tarentaise comparées aux autres pessières alpestres. Ver. Geobot. Inst. ETH Zürich 43: 104-139. 
Goldberg, S., Lebron, I. \& Suarez, D.L. 2000. Soil colloidal behavior. In: Sumner, M.E. (ed.) Handbook of soil science, pp. B195-B240. CRC Press, Boca Raton.

Greenacre, M.J. 1984. Theory and applications of correspondence analysis. Academic Press, London.

Heath, G.H., Luckwill, L.C. \& Pullen, O.J. 1938. The rooting systems of heath plants, with a section on the underground organs of heath bryophytes. J. Ecol. 26: 331-352.

Ingestad, T. 1973. Mineral nutrient requirements of Vaccinium vitis-idaea and V. myrtillus. Physiol. Plant. 29: 239-246.

Jäderlund, A., Zackrisson, O., Dahlberg, A. \& Nilsson, M.C. 1997. Interference of Vaccinium myrtillus on establishment, growth, and nutrition of Picea abies seedlings in a northern boreal site. Can. J. For. Res. 27: 2017-2025.

Jäderlund, A., Zackrisson, O. \& Nilsson, M.C. 1996. Effects of bilberry (Vaccinium myrtillus L.) litter on seed germination and early seedling growth of four boreal tree species. J. Chem. Ecol. 22: 973-986.

Kilbertus, G. 1968. Vitesse de décomposition de Pseudoscleropodium purum (Hedw.) Fleisch dans la nature. Rev. Ecol. Biol. Sol 5: 237-244.

Kononova, M.M. 1961. Soil organic matter, its nature, its role in soil formation and in soil fertility. Pergamon Press, New York.

Körner, C. 1999. Alpine plant life. Functional plant ecology of high mountain ecosystems. Springer, Berlin.

Lichtenegger, E. 1996. Root distribution in some alpine plants. Acta Phytogeogr. Suec. 81: 76-82. 
Loranger, G., Bandyopadhyaya, I., Razaka, B. \& Ponge, J.F. 2001. Does soil acidity explain altitudinal sequences in Collembolan communities? Soil Biol. Biochem. 33: 381-393.

Maubon, M., Ponge, J.F. \& André, J. 1995. Dynamics of Vaccinium myrtillus patches in mountain spruce forest. J. Veg. Sci. 6: 343-348.

McQueen, D.R. 1968. The quantitative distribution of absorbing roots of Pinus silvestris and Fagus sylvatica in a forest succession. Oecol. Plant. 3: 83-99.

Messier, C. \& Kimmins, J.P. 1991. Above- and below-ground vegetation recovery in recently clearcut and burned sites dominated by Gaultheria shallon in coastal British Columbia. For. Ecol. Manag. 46: 275-294.

Näsholm, T., Ekblad, A., Nordin, A., Giesler, R., Högberg, A. \& Högberg, P. 1998. Boreal forest plants take up organic nitrogen. Nature 392: 914-916.

Northup, R.R., Dahlgren, R.A. \& McColl, J.G. 1998. Polyphenols as regulators of plant-litter-soil interactions in northern California's pygmy forest: a positive feedback? Biogeochemistry 42: 189-220.

Peltier, A., Ponge, J.F., Jordana, R. \& Ariño, A. 2001. Humus forms in Mediterranean scrublands with aleppo pine. Soil Sci. Soc. Am. J. 65: 884-896.

Ponge, J.F. 1984. Étude écologique d'un humus forestier par l'observation d'un petit volume, premiers résultats. I. La couche $L_{1}$ d'un moder sous pin sylvestre. Rev. Ecol. Biol. Sol 21: 161-187.

Ponge, J.F. 1988. Étude écologique d'un humus forestier par l'observation d'un petit volume. III. La couche $F_{1}$ d'un moder sous Pinus sylvestris. Pedobiologia 31: 1-64. 
Ponge, J.F. 1999. Horizons and humus forms in beech forests of the Belgian Ardennes. Soil Sci. Soc. Am. J. 63: 1888-1901.

Ponge, J.F., André, J., Bernier, N. \& Gallet, C. 1994. La régénération naturelle: connaissances actuelles. Le cas de l'épicéa en forêt de Macot (Savoie). Rev. For. Fr. 46: 25-45.

Ponge, J.F., André, J., Zackrisson, O., Bernier, N., Nilsson, M.C. \& Gallet, C. 1998. The forest regeneration puzzle: biological mechanisms in humus layer and forest vegetation dynamics. BioScience 48: 523-530.

Ponge, J.F., Charnet, F. \& Allouard, J.M. 2000. Comment distinguer dysmoder et mor? L'exemple de la forêt domaniale de Perche-Trappe (Orne). Rev. For. Fr. 52: 23-37.

Ponge, J.F. \& Delhaye, L. 1995. The heterogeneity of humus profiles and earthworm communities in a virgin forest. Biol. Fertil. Soils 20: 24-32.

Rameau, J.C., Mansion, D., Dumé, G., Lecointe, A., Timbal, J., Dupont, P. \& Keller, R. 1993. Flore forestière française, guide écologique illustré. II. Montagnes. Institut pour le Développement Forestier, Paris.

Read, D.J. \& Kerley, S. 1995. The status and function of ericoid mycorrhizal systems. In: Varma, A. \& Hock, B. (eds.) Mycorrhiza: structure, function, molecular biology and biotechnology, pp. 499520. Springer-Verlag, Berlin

Schoenau, J.J. \& Bettany, J.R. 1987. Organic matter leaching as a component of carbon, nitrogen, phosphorus, and sulfur cycles in a forest, grassland, and gleyed soil. Soil Sci. Soc. Am. J. 51: 646-651.

Sokal, R.R. \& Rohlf, F.J. 1995. Biometry. The principles and practice of statistics in biological research, $3^{\text {rd }}$ ed. W.H. Freeman and Company, New York. 
Tamm, C.O. 1953. Growth, yield and nutrition in carpets of a forest moss (Hylocomium splendens). Medd. Stat. Skogsforskningsinst. № 43.

Topoliantz, S., Ponge, J.F. \& Viaux, P. 2000. Earthworm and enchytraeid activity under different arable farming systems, as exemplified by biogenic structures. Plant Soil 225: 39-51.

Wardle, D.A., Zackrisson, O., Hörnberg, G. \& Gallet, C. 1997. The influence of island area on ecosystem properties. Science 277: 1296-1299. 


\section{Legends of figures}

Fig. 1. Correspondence analysis on the data matrix with 159 humus components as active variables and 53 samples as observations. Elevation and depth levels and horizon types were put as additional (passive) variables. Projection of active and passive variables in the plane of the first two factorial axes, extracting 13 and $9 \%$ of the total variance, respectively.

Fig. 2. Correlation between Axis 1 coordinates of the 159 humus components and their mean depth (see text and Table 1).

Fig. 3. The influence of profile depth on the abundance of spruce roots and bilberry roots or rhizomes in a micro-podzol (1870m altitude).

Fig. 4. The influence of profile depth on the abundance of spruce roots and bilberry roots or rhizomes in an old rodent mound ( $1650 \mathrm{~m}$ altitude).

Fig. 5. Dependence of litter thickness $(\mathrm{OL}+\mathrm{OF}+\mathrm{OH}$ horizons) on altitude in the 12 humus profiles studied.

Fig. 6. Dependence of the mean relative volume of faecal material on altitude in the 12 humus profiles studied. 


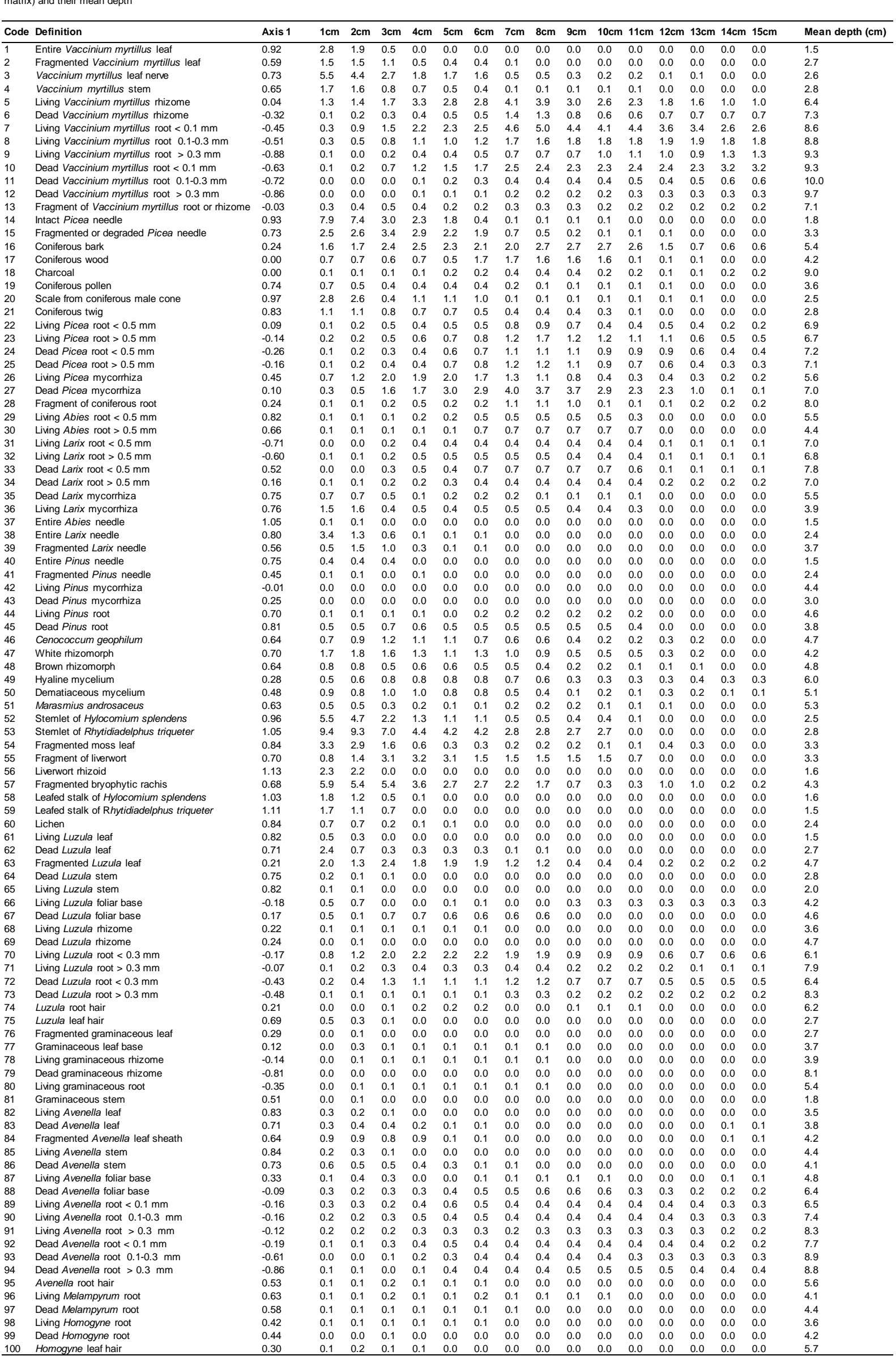


Table 1. (continued)

\begin{tabular}{|c|c|c|c|c|c|c|c|c|c|c|c|c|c|c|c|c|c|c|}
\hline Code & Definition & Axis 1 & $1 \mathrm{~cm}$ & $2 \mathrm{~cm}$ & $3 \mathrm{~cm}$ & $4 \mathrm{~cm}$ & $5 \mathrm{~cm}$ & $6 \mathrm{~cm}$ & $7 \mathrm{~cm}$ & $8 \mathrm{~cm}$ & $9 \mathrm{~cm}$ & $10 \mathrm{~cm}$ & $11 \mathrm{~cm}$ & $12 \mathrm{~cm}$ & $13 \mathrm{~cm}$ & $14 \mathrm{~cm}$ & $15 \mathrm{~cm}$ & Mean depth $(\mathrm{cm})$ \\
\hline 101 & Homogyne flower stem & 0.74 & 0.1 & 0.1 & 0.0 & 0.0 & 0.0 & 0.0 & 0.0 & 0.0 & 0.0 & 0.0 & 0.0 & 0.0 & 0.0 & 0.0 & 0.0 & 2.4 \\
\hline 102 & Fragmented Asteraceae leaf & 0.43 & 0.4 & 0.4 & 0.0 & 0.0 & 0.0 & 0.0 & 0.0 & 0.0 & 0.0 & 0.0 & 0.0 & 0.0 & 0.0 & 0.0 & 0.0 & 2.3 \\
\hline 103 & Living Asteraceae root & -0.11 & 0.1 & 0.4 & 0.3 & 0.3 & 0.3 & 0.3 & 0.3 & 0.3 & 0.0 & 0.0 & 0.0 & 0.0 & 0.0 & 0.0 & 0.0 & 3.6 \\
\hline 104 & Dead Asteraceae root & -0.17 & 0.0 & 0.1 & 0.1 & 0.1 & 0.1 & 0.1 & 0.1 & 0.1 & 0.0 & 0.0 & 0.0 & 0.0 & 0.0 & 0.0 & 0.0 & 6.1 \\
\hline 105 & Living Asteraceae leaf base & 0.15 & 0.2 & 0.6 & 0.1 & 0.1 & 0.1 & 0.1 & 0.1 & 0.1 & 0.0 & 0.0 & 0.0 & 0.0 & 0.0 & 0.0 & 0.0 & 3.8 \\
\hline 106 & Vaccinium vitis-idaea leaf & 0.42 & 0.0 & 0.1 & 0.1 & 0.2 & 0.0 & 0.0 & 0.0 & 0.0 & 0.0 & 0.0 & 0.0 & 0.0 & 0.0 & 0.0 & 0.0 & 3.3 \\
\hline 107 & Living Vaccinium vitis-idaea root & -0.03 & 0.1 & 0.1 & 0.1 & 0.2 & 0.1 & 0.1 & 0.2 & 0.2 & 0.2 & 0.2 & 0.2 & 0.2 & 0.1 & 0.0 & 0.0 & 7.0 \\
\hline 108 & Dead Vaccinium vitis-idaea root & 0.03 & 0.0 & 0.0 & 0.1 & 0.1 & 0.0 & 0.0 & 0.0 & 0.0 & 0.0 & 0.1 & 0.1 & 0.0 & 0.0 & 0.0 & 0.0 & 6.8 \\
\hline 109 & Living Vaccinium vitis-idaea rhizome & 0.55 & 0.0 & 0.0 & 0.2 & 0.3 & 0.0 & 0.0 & 0.0 & 0.1 & 0.1 & 0.0 & 0.0 & 0.0 & 0.0 & 0.0 & 0.0 & 5.1 \\
\hline 110 & Dead Vaccinium vitis-idaea rhizome & 0.82 & 0.0 & 0.0 & 0.0 & 0.0 & 0.0 & 0.0 & 0.0 & 0.0 & 0.0 & 0.0 & 0.0 & 0.0 & 0.0 & 0.0 & 0.0 & 3.1 \\
\hline 111 & Fragmented Vaccinium vitis-idaea stem & 0.47 & 0.0 & 0.0 & 0.0 & 0.0 & 0.0 & 0.0 & 0.0 & 0.0 & 0.0 & 0.0 & 0.0 & 0.0 & 0.0 & 0.0 & 0.0 & 4.3 \\
\hline 112 & Living Oxalis root & 0.82 & 0.2 & 0.2 & 0.2 & 0.4 & 0.4 & 0.4 & 0.1 & 0.1 & 0.1 & 0.0 & 0.0 & 0.0 & 0.0 & 0.0 & 0.0 & 3.9 \\
\hline 113 & Dead Oxalis root & 0.96 & 0.2 & 0.2 & 0.1 & 0.1 & 0.1 & 0.1 & 0.1 & 0.1 & 0.1 & 0.1 & 0.0 & 0.0 & 0.0 & 0.0 & 0.0 & 4.0 \\
\hline 114 & Living Oxalis leaf base & 0.90 & 0.1 & 0.0 & 0.1 & 0.2 & 0.2 & 0.2 & 0.0 & 0.0 & 0.0 & 0.0 & 0.0 & 0.0 & 0.0 & 0.0 & 0.0 & 3.1 \\
\hline 115 & Dead Oxalis leaf base & 0.91 & 0.0 & 0.0 & 0.0 & 0.0 & 0.0 & 0.0 & 0.0 & 0.0 & 0.0 & 0.0 & 0.0 & 0.0 & 0.0 & 0.0 & 0.0 & 3.5 \\
\hline 116 & Fragmented Alchemilla leaf base & 0.36 & 0.0 & 0.1 & 0.1 & 0.1 & 0.0 & 0.0 & 0.0 & 0.0 & 0.0 & 0.0 & 0.0 & 0.0 & 0.0 & 0.0 & 0.0 & 2.6 \\
\hline 117 & Alchemilla miscellaneous fragment & 0.02 & 0.0 & 0.1 & 0.0 & 0.0 & 0.0 & 0.0 & 0.0 & 0.0 & 0.0 & 0.0 & 0.0 & 0.0 & 0.0 & 0.0 & 0.0 & 3.2 \\
\hline 118 & Living Alchemilla root & 0.14 & 0.0 & 0.1 & 0.0 & 0.0 & 0.1 & 0.1 & 0.0 & 0.0 & 0.0 & 0.0 & 0.0 & 0.0 & 0.0 & 0.0 & 0.0 & 4.2 \\
\hline 119 & Dead Alchemilla root & -0.69 & 0.0 & 0.0 & 0.0 & 0.0 & 0.0 & 0.0 & 0.0 & 0.0 & 0.0 & 0.0 & 0.0 & 0.0 & 0.0 & 0.0 & 0.0 & 8.5 \\
\hline 120 & Herbaceous plant tissue & 0.21 & 0.4 & 1.0 & 0.9 & 0.9 & 1.1 & 1.1 & 0.6 & 0.6 & 0.2 & 0.2 & 0.2 & 0.2 & 0.1 & 0.2 & 0.2 & 6.5 \\
\hline 121 & Spore & 0.29 & 0.1 & 0.2 & 0.1 & 0.1 & 0.1 & 0.1 & 0.0 & 0.0 & 0.0 & 0.0 & 0.0 & 0.0 & 0.0 & 0.1 & 0.1 & 4.8 \\
\hline 122 & Bud fragment & 0.70 & 0.2 & 0.2 & 0.2 & 0.1 & 0.1 & 0.1 & 0.0 & 0.0 & 0.0 & 0.0 & 0.0 & 0.0 & 0.0 & 0.1 & 0.1 & 2.8 \\
\hline 123 & Exuvia & 0.70 & 0.1 & 0.1 & 0.1 & 0.0 & 0.0 & 0.0 & 0.0 & 0.0 & 0.0 & 0.0 & 0.0 & 0.0 & 0.0 & 0.0 & 0.0 & 3.5 \\
\hline 124 & Miscellaneous plant fragment & 0.46 & 0.0 & 0.1 & 0.1 & 0.0 & 0.0 & 0.0 & 0.0 & 0.0 & 0.0 & 0.0 & 0.0 & 0.0 & 0.0 & 0.0 & 0.0 & 3.8 \\
\hline 125 & Animal hair & 0.78 & 0.1 & 0.1 & 0.1 & 0.1 & 0.1 & 0.1 & 0.0 & 0.0 & 0.0 & 0.0 & 0.0 & 0.0 & 0.0 & 0.0 & 0.0 & 3.3 \\
\hline 126 & Organic enchytraeid faeces & 0.45 & 1.9 & 3.4 & 6.8 & 10.1 & 7.8 & 7.9 & 6.1 & 5.6 & 4.3 & 3.0 & 2.2 & 2.0 & 1.9 & 0.6 & 0.6 & 5.2 \\
\hline 127 & Organic epigeic earthworm faeces & 0.64 & 2.3 & 3.1 & 5.0 & 4.2 & 4.3 & 3.2 & 2.0 & 1.8 & 1.2 & 1.0 & 0.4 & 0.2 & 0.2 & 0.1 & 0.1 & 4.1 \\
\hline 128 & Organic silver faecal material & 0.56 & 1.0 & 1.2 & 2.6 & 2.7 & 3.7 & 3.7 & 2.0 & 1.3 & 1.2 & 1.0 & 0.7 & 0.4 & 0.3 & 0.2 & 0.2 & 4.8 \\
\hline 129 & Organic collembolan faeces & 0.55 & 0.2 & 0.3 & 0.3 & 0.2 & 0.2 & 0.1 & 0.1 & 0.1 & 0.1 & 0.1 & 0.1 & 0.0 & 0.0 & 0.0 & 0.0 & 3.6 \\
\hline 130 & Organic plate-like faeces & 0.61 & 0.4 & 0.4 & 0.3 & 0.3 & 0.2 & 0.1 & 0.1 & 0.1 & 0.2 & 0.2 & 0.2 & 0.1 & 0.1 & 0.2 & 0.2 & 5.4 \\
\hline 131 & Organic insect larvae faeces & 0.36 & 0.0 & 0.0 & 0.2 & 0.2 & 0.1 & 0.1 & 0.0 & 0.0 & 0.0 & 0.0 & 0.0 & 0.0 & 0.0 & 0.1 & 0.1 & 5.2 \\
\hline 132 & Organic mite faeces & 0.48 & 0.1 & 0.1 & 0.1 & 0.4 & 0.0 & 0.1 & 0.0 & 0.0 & 0.0 & 0.0 & 0.0 & 0.0 & 0.0 & 0.0 & 0.0 & 4.7 \\
\hline 133 & Organic millipede faeces & 0.67 & 1.0 & 1.0 & 1.2 & 0.9 & 0.8 & 0.6 & 0.4 & 0.2 & 0.2 & 0.2 & 0.1 & 0.0 & 0.0 & 0.2 & 0.2 & 3.4 \\
\hline 134 & Organo-mineral enchytraeid faeces & 0.20 & 0.2 & 0.2 & 3.6 & 3.9 & 4.3 & 4.6 & 4.6 & 4.8 & 4.3 & 4.3 & 2.7 & 1.2 & 1.0 & 1.0 & 1.0 & 7.6 \\
\hline 135 & Organo-mineral endogeic earthworm faeces & -0.58 & 0.1 & 0.9 & 1.5 & 2.2 & 2.4 & 2.7 & 2.8 & 3.1 & 2.5 & 2.5 & 2.8 & 2.4 & 2.2 & 2.2 & 2.2 & 8.3 \\
\hline 136 & Organo-mineral anecic earthworm faeces & -0.38 & 0.0 & 0.0 & 0.6 & 1.4 & 1.4 & 1.3 & 1.3 & 1.3 & 1.3 & 1.3 & 1.3 & 0.6 & 0.5 & 0.4 & 0.4 & 6.6 \\
\hline 137 & Mineral endogeic earthworm faeces & -0.76 & 0.0 & 0.1 & 0.8 & 0.9 & 0.9 & 1.7 & 2.0 & 2.8 & 2.7 & 2.7 & 2.7 & 2.0 & 1.9 & 3.3 & 3.3 & 8.9 \\
\hline 138 & Mineral enchytraeid faeces & -0.79 & 0.0 & 0.1 & 0.8 & 1.0 & 1.0 & 1.0 & 1.7 & 2.1 & 3.4 & 3.4 & 3.3 & 2.6 & 2.0 & 1.6 & 1.6 & 8.2 \\
\hline 139 & Organo-mineral granular aggregates & -1.36 & 0.0 & 0.0 & 0.2 & 0.3 & 0.5 & 0.5 & 0.5 & 0.5 & 0.8 & 0.8 & 1.1 & 1.2 & 1.8 & 1.4 & 1.4 & 11.3 \\
\hline 140 & Organo-mineral crumb aggregates & -1.15 & 0.1 & 0.1 & 0.2 & 0.4 & 0.4 & 0.4 & 0.4 & 0.4 & 0.9 & 1.0 & 1.1 & 1.4 & 1.9 & 3.3 & 3.3 & 11.8 \\
\hline 141 & Organo-mineral polyedric aggregates & -1.27 & 0.0 & 0.0 & 0.0 & 0.6 & 0.7 & 0.7 & 1.2 & 1.2 & 1.4 & 1.4 & 2.5 & 1.9 & 1.8 & 2.3 & 2.3 & 10.5 \\
\hline 142 & Mineral particulate aggregates & -1.70 & 0.0 & 0.0 & 0.0 & 0.0 & 3.8 & 3.8 & 5.7 & 5.7 & 7.5 & 9.4 & 9.4 & 9.4 & 8.1 & 4.7 & 4.7 & 11.7 \\
\hline 143 & Mineral granular aggregates & -1.60 & 0.0 & 0.0 & 0.0 & 0.2 & 0.3 & 0.3 & 0.5 & 0.5 & 0.6 & 1.8 & 1.8 & 2.0 & 1.8 & 0.8 & 0.8 & 11.7 \\
\hline 144 & Mineral crumb aggregates & -1.41 & 0.0 & 0.0 & 0.1 & 0.4 & 0.4 & 1.0 & 1.0 & 1.0 & 1.3 & 3.0 & 3.8 & 4.5 & 6.0 & 5.4 & 5.4 & 12.7 \\
\hline 145 & Mineral polyedric aggregates & -1.51 & 0.0 & 0.0 & 0.0 & 0.0 & 0.1 & 0.1 & 0.1 & 0.1 & 0.9 & 1.5 & 1.8 & 1.8 & 2.9 & 2.9 & 2.9 & 12.1 \\
\hline 146 & Coarse gravel & -1.53 & 0.0 & 0.0 & 0.0 & 0.2 & 0.6 & 0.6 & 0.9 & 0.9 & 2.2 & 2.3 & 2.4 & 2.8 & 3.4 & 5.2 & 5.2 & 12.2 \\
\hline 147 & Fine gravel & -1.48 & 0.0 & 0.0 & 0.0 & 0.1 & 0.2 & 0.2 & 0.7 & 0.7 & 1.9 & 2.0 & 2.1 & 2.3 & 2.2 & 2.5 & 2.5 & 11.7 \\
\hline 148 & Coarse sand & -1.42 & 0.0 & 0.1 & 0.1 & 0.4 & 0.4 & 0.4 & 0.6 & 0.6 & 1.2 & 1.4 & 1.4 & 1.7 & 2.1 & 4.0 & 4.0 & 12.3 \\
\hline 149 & Fine sand & -1.28 & 0.0 & 0.1 & 0.2 & 0.6 & 0.6 & 0.6 & 0.8 & 0.8 & 1.6 & 1.6 & 1.7 & 2.3 & 2.3 & 2.1 & 2.1 & 11.1 \\
\hline 150 & Silt & -1.37 & 0.0 & 0.0 & 0.5 & 0.9 & 0.9 & 0.9 & 1.8 & 1.8 & 3.2 & 3.2 & 3.4 & 3.5 & 3.6 & 3.2 & 3.2 & 11.0 \\
\hline 151 & Boulder & -1.49 & 0.0 & 0.0 & 0.3 & 1.4 & 1.7 & 1.7 & 2.9 & 2.9 & 5.8 & 6.4 & 6.5 & 6.6 & 9.8 & 13.6 & 13.6 & 11.8 \\
\hline 152 & Quartz grain & -0.81 & 0.1 & 0.1 & 0.3 & 0.2 & 0.2 & 0.3 & 0.3 & 0.5 & 0.9 & 1.0 & 0.9 & 0.8 & 0.8 & 1.2 & 1.2 & 7.8 \\
\hline 153 & Mineral fragment & -0.66 & 0.0 & 0.0 & 0.1 & 0.1 & 0.1 & 0.0 & 0.1 & 0.1 & 0.1 & 0.1 & 0.1 & 0.1 & 0.1 & 0.2 & 0.2 & 7.3 \\
\hline 154 & Enchytraeid & 0.05 & 0.0 & 0.0 & 0.1 & 0.1 & 0.1 & 0.1 & 0.1 & 0.1 & 0.1 & 0.1 & 0.0 & 0.0 & 0.0 & 0.0 & 0.0 & 6.6 \\
\hline 155 & Epigeic earthworm & 0.64 & 0.1 & 0.1 & 0.0 & 0.0 & 0.0 & 0.0 & 0.0 & 0.0 & 0.0 & 0.0 & 0.0 & 0.0 & 0.0 & 0.0 & 0.0 & 1.6 \\
\hline 156 & Collembolan & 0.71 & 0.0 & 0.0 & 0.0 & 0.0 & 0.0 & 0.0 & 0.0 & 0.0 & 0.0 & 0.0 & 0.0 & 0.0 & 0.0 & 0.0 & 0.0 & 4.5 \\
\hline 157 & Mite & 0.81 & 0.1 & 0.1 & 0.1 & 0.1 & 0.1 & 0.0 & 0.0 & 0.0 & 0.0 & 0.0 & 0.0 & 0.0 & 0.0 & 0.0 & 0.0 & 2.8 \\
\hline 158 & Lava & -0.84 & 0.0 & 0.0 & 0.0 & 0.0 & 0.0 & 0.0 & 0.0 & 0.0 & 0.0 & 0.0 & 0.0 & 0.0 & 0.0 & 0.0 & 0.0 & 6.3 \\
\hline 159 & Millipede & 0.86 & 0.0 & 0.0 & 0.0 & 0.0 & 0.0 & 0.0 & 0.0 & 0.0 & 0.0 & 0.0 & 0.0 & 0.0 & 0.0 & 0.0 & 0.0 & 1.5 \\
\hline
\end{tabular}




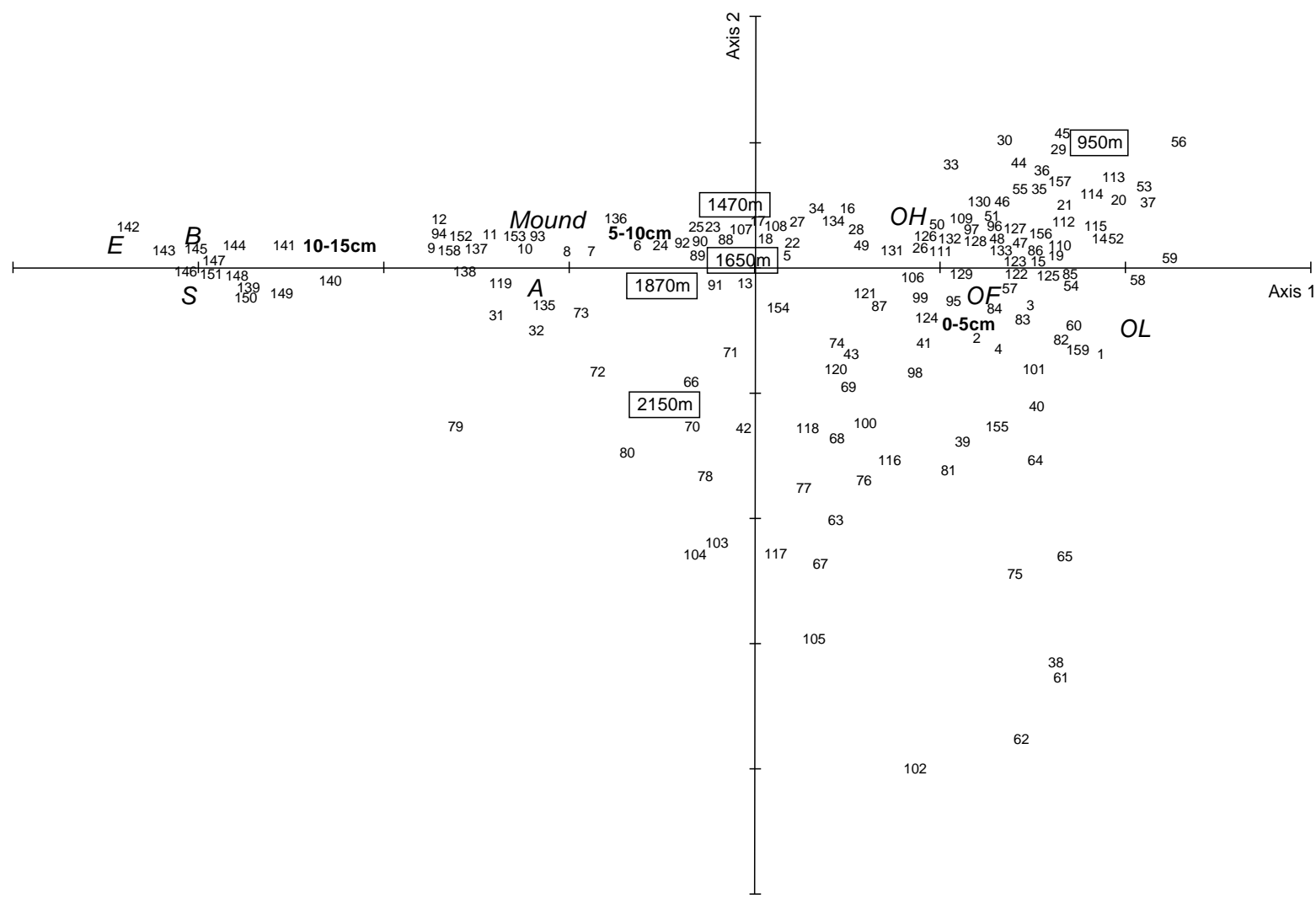

Fig. 1 


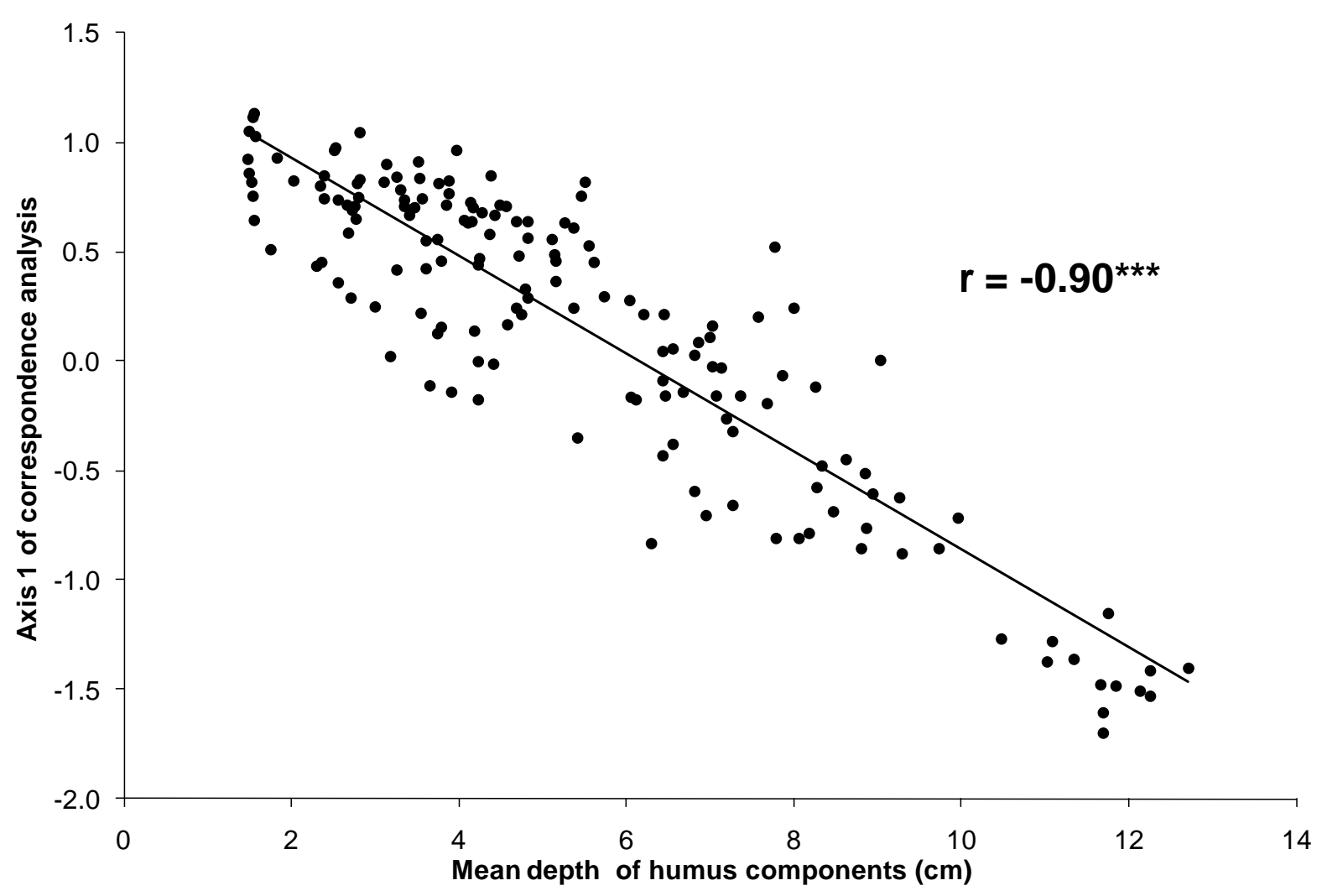

Fig. 2 


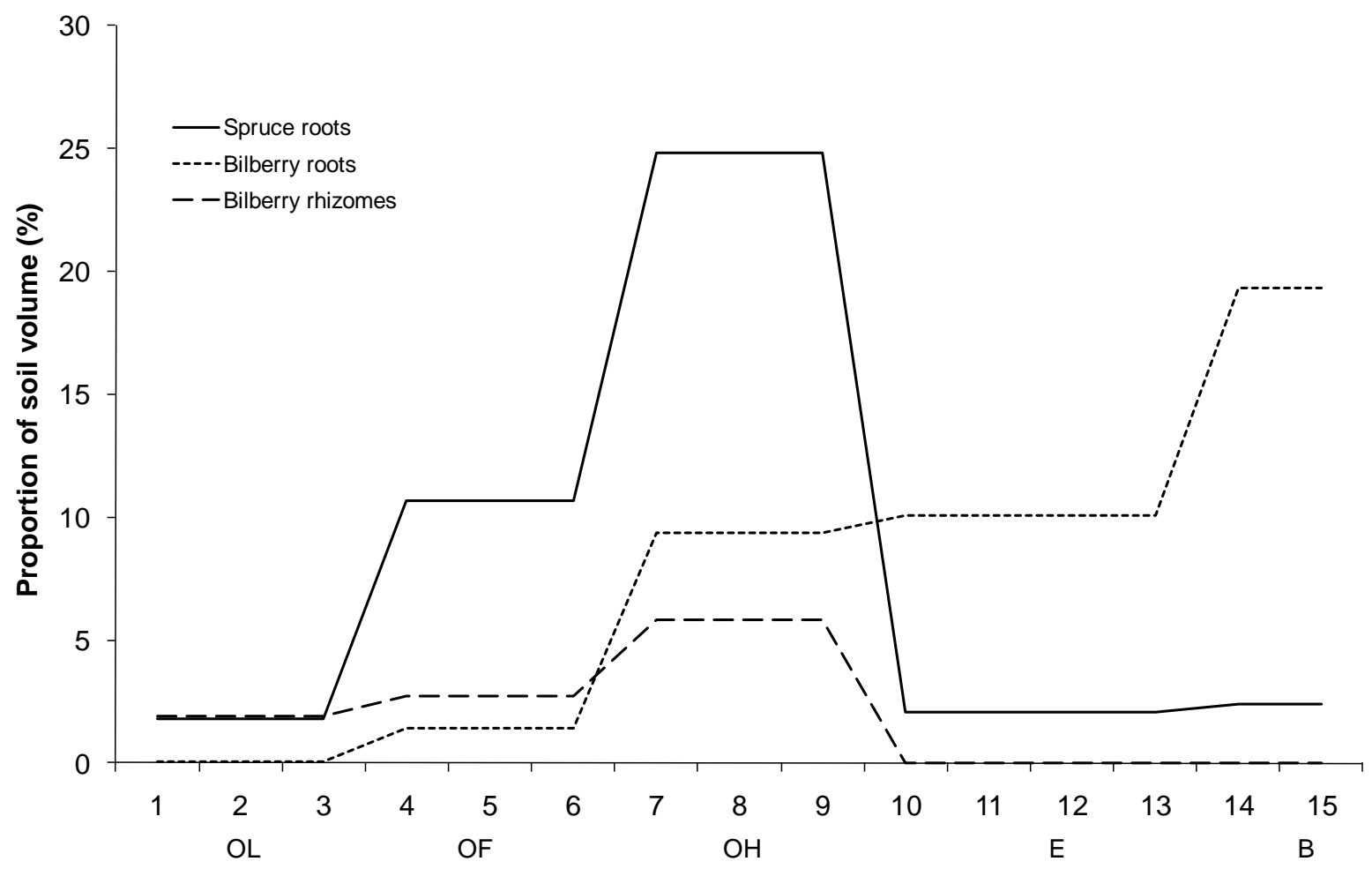

Profile depth (cm)

Fig. 3 


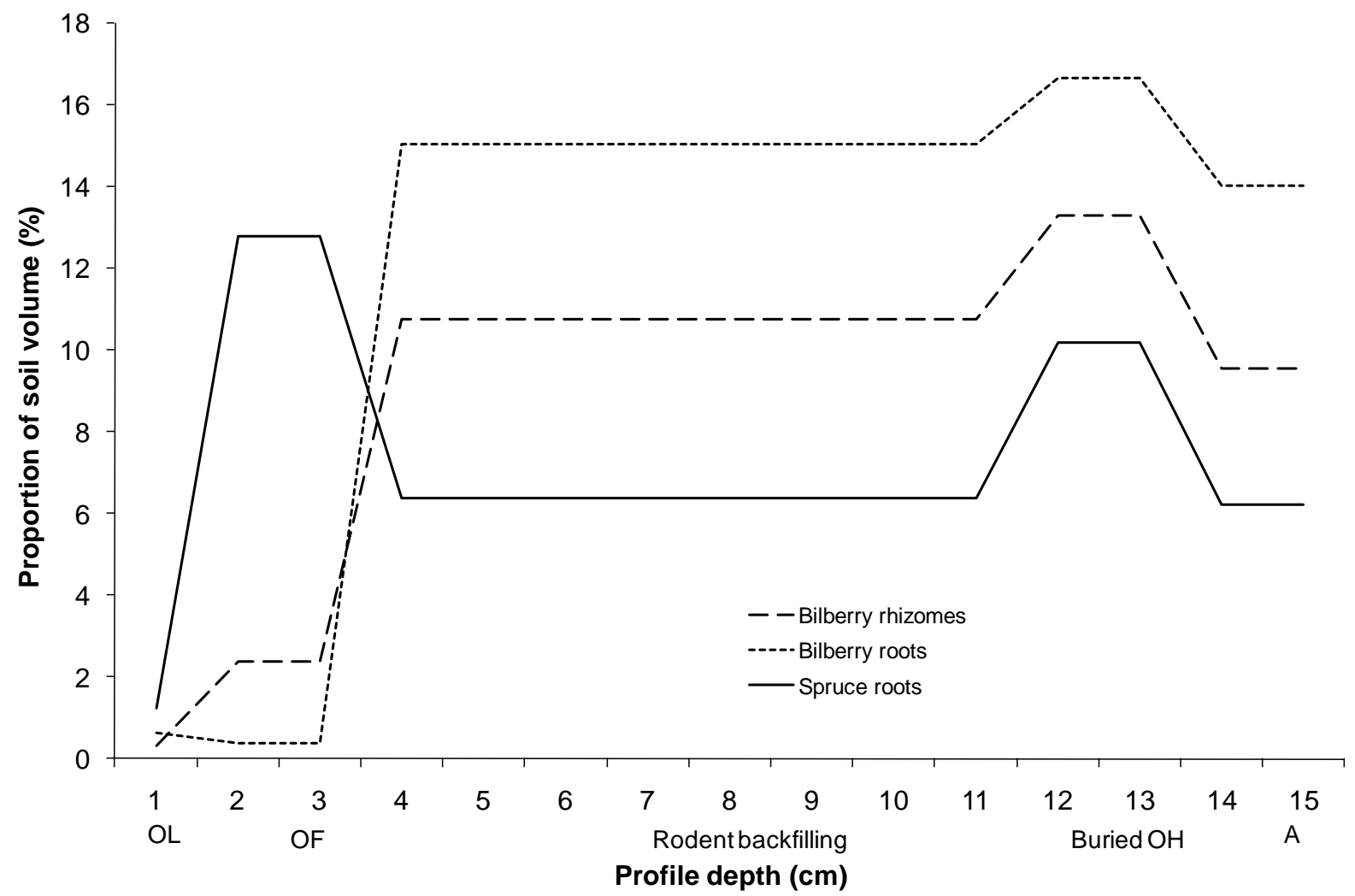

Fig. 4 


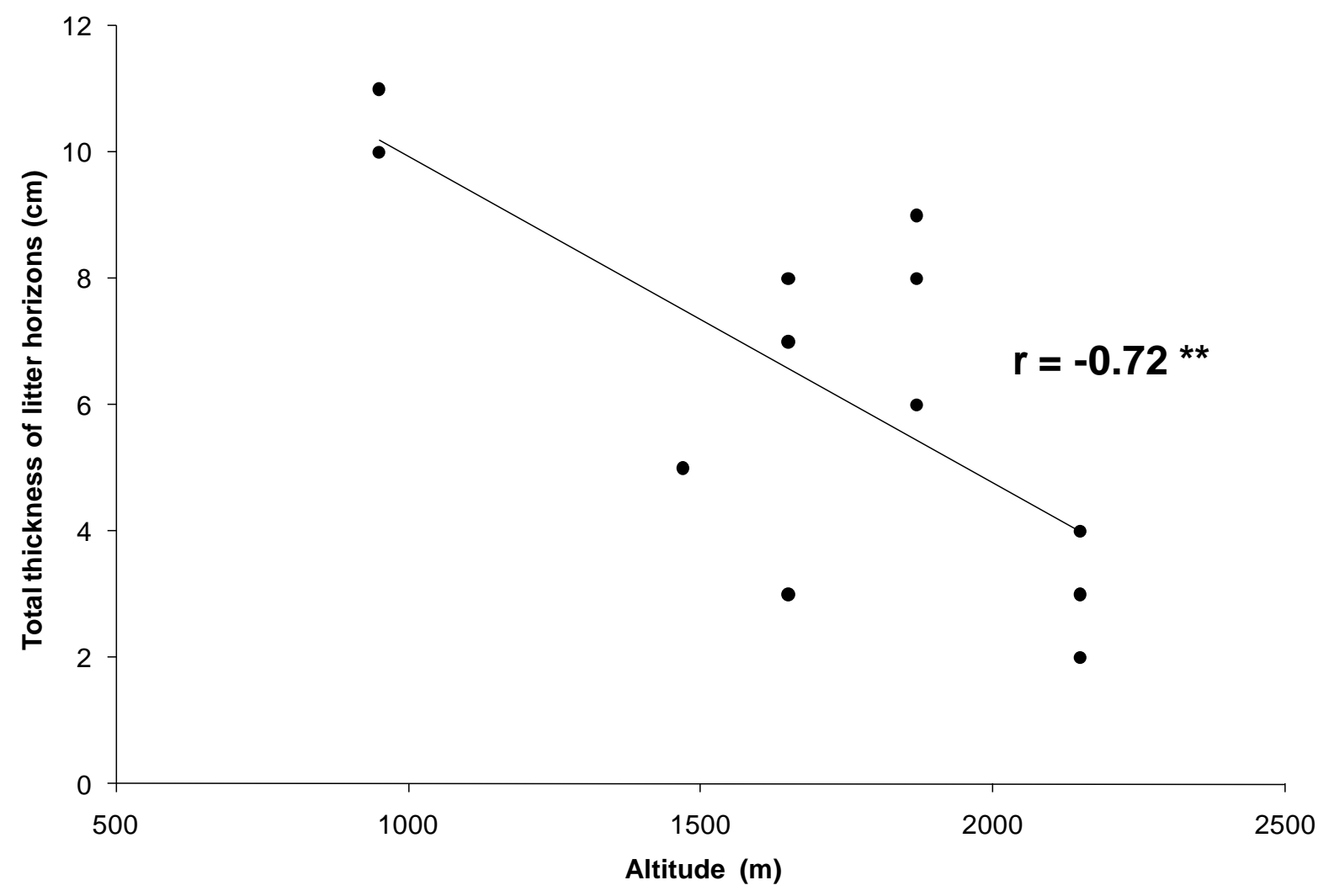

Fig. 5 


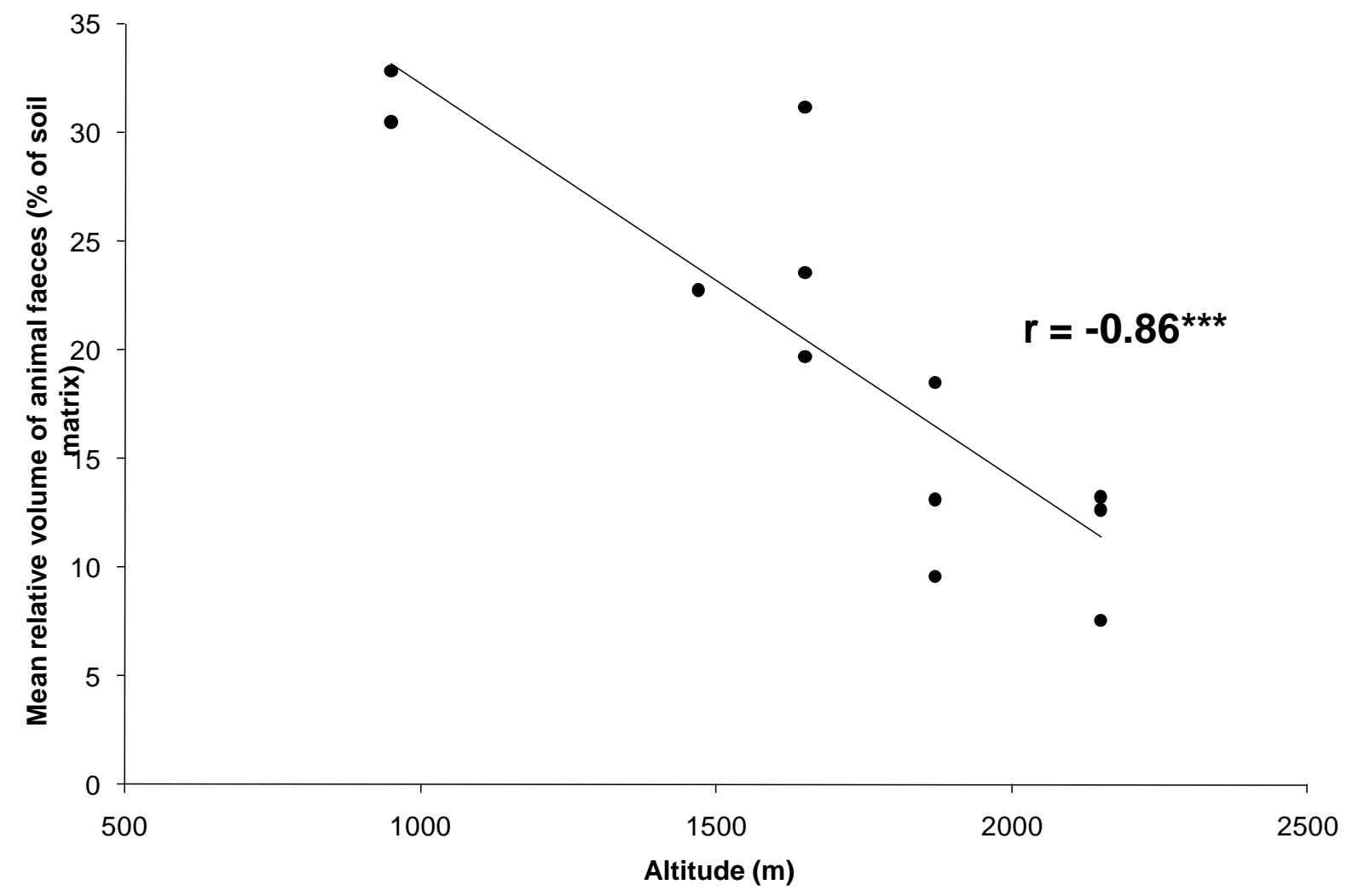

Fig. 6 